\title{
A History of Mediation
}

Zege's monasteries have historically been notable for their high degree of autonomy from the state, and for their extensive administrative powers, serving as "the basis of administration, taxation, and court arbitration" (Binayew 2014: xi). This did not necessarily mean that the monasteries were simply felt to be extensions of the state. Several local scholars have described to me how the monasteries have acted to shelter the populace from state extraction. In one example, I was told how the Emperor Menilek had fallen sick and had relieved the peninsula of all taxation in order to gain the blessing of the monasteries. Bosc-Tiessé (2008), too, shows how adept monasteries were in holding state officials at bay through a careful mix of flattery and moral admonition. Nonetheless, their degree of authority and control over resources made the monastic associations (mahber) an important center of political power in their own right.

The political power of monasteries, as of the Orthodox Church as a whole, has greatly diminished since the fall of Emperor Haile Selassie in 1974, under both the military-socialist Derg regime and the current secular federalist government. Careful analysis shows that in fact the encroachment of secular bureaucratic institutions into domains of church authority has been going on for at least a century (Clapham 1969, Binayew 2014). Orthodox Christians in Zege generally present the decline of monastic authority in nostalgic terms, suggesting that recent history is marked by a generalized weakening of hospitality norms and religious ethics, and that the monasteries remain the only legitimate moral authority on the peninsula.

It is not so simple, however, to identify who has historically represented monastic authority in Zege. Alongside clerical authorities-the monks, deacons, and sometimes priests-there exists a class of high-status landholders (balabbat, 
"patriarch," literally "one who has a father") who, while not part of the clergy, have maintained close associations with the church-monasteries and have historically wielded significant political and jural power in Zege. There were also key political figures who combined church and lay authority, chiefly the mislené $e^{1}$ and the liqered, ${ }^{2}$ both of which titles still exist in Zege today, albeit with reduced scope. Both mislené and líqered have existed in two forms, one representing the church and one the society (yager, "of the land"), which further complicates efforts to untangle the precise relationships involved. But it is clear that lígered, for example, historically controlled much of the production of coffee from church lands (Binayew 2014), and therefore wielded significant political and economic power.

This chapter aims to develop an outline of historic trajectories of monastic and political power in Zege-or at least, to show how these are remembered today. In so doing I hope to give the reader a sense of how Zege fits within the broader scope of the history of Ethiopian Orthodox Christianity and the Ethiopian state, and of why fasting and prohibition have become such points of emphasis. I argue that many in Zege, especially older Orthodox Christians, remember recent history in terms of a decline of hospitality and feasting practices, especially funerary feasting. These practices were associated with landholding classes closely related to (but not identical with) the monastic authorities. I will suggest that Orthodox religious practice in Zege is not itself in decline, but has been reimagined to focus on practices such as fasting. Compared with those of the imperial era, these practices point less toward marking class relations within Orthodox society, and more to defining Orthodox Christians vis-à-vis the state and other religions (especially Islam and Protestantism). But they retain the key principles of prohibition and mediation that underpin socioreligious logic.

\section{ZEGE WITHIN ETHIOPIAN ORTHODOX HISTORY}

Some local church literature places the foundation of Zege's first monastery by Abune Betre Maryam around 1270 AD. Other historical sources, however, suggest that Betre Maryam lived during the reign of Emperor Amde Sion (1314-44; Cerulli 1946, Derat 2003: 507). This places the foundation of Zege's monastic community in a period marked by the consolidation of the Solomonic monarchy, whose legitimacy was tied closely to the church and the claim to descend from King Solomon. This was also a period of monastic revival and the rapid southward expansion of Orthodox-Imperial territory across Lake Tana and far beyond (Taddesse 1972b, Ephraim 2013). The monasteries of Lake Tana have since come to be considered as one of the heartlands of Orthodox territory.

The early history of Christianity in Ethiopia has been told many times, but some key points are worth mentioning here. Christianity appears to have spread in top-down fashion, beginning with the conversion of King Ezana of Axum in 
the late 30os. This came in the context of centuries-old, bidirectional relationships between the kingdoms of the northeastern Horn of Africa and the Mediterranean, the Levant, and the Arabian Gulf (Finneran 2007). The Ethiopic script dates also from the third and fourth centuries and is associated with Ge'ez, a language extinct in the vernacular but very much alive as the language of Orthodox liturgy.

The Ethiopic script and the Orthodox Church have become closely associated with the Amharic- and Tigrayan-speaking societies that have dominated the northern highlands of Ethiopia. These societies, distinguished by Orthodox Christian dominance, plough agriculture, and a military-feudal class system, are sometimes referred to as "Abyssinian" to distinguish them from the other peoples who make up the contemporary Ethiopian nation-state. This designation, however, can obscure the diversity and historical mixture of northern Ethiopia. The area around Zege, for example, while almost entirely Amharic-speaking, has been home to speakers of Agew and to important non-Christian groups including Weyto and Beta Israel. Significant influence, and significant slave-descended populations, from Benishangul-Gumuz to the west are also evident (Taddesse 1972b, 1994, James 1986).

The Ethiopian Orthodox Tewahido Church itself is usually classified with the "Oriental Orthodox" churches of Armenia, Syria, and Egypt. These churches split from the mainstream at the Council of Chalcedon in 451, over a Christological dispute. The question was whether Christ was of two natures (phusis), divine and human, or one nature, divine and human combined (Binns 2002). The oriental churches dissented from the official two-natures declaration, and so came to be known as the "monophysites." This term is now considered derogatory, and has been replaced by "miaphysite," which means the same thing but without the insulting connotations (Fisseha 2002). Even still, there are many who question whether the Ethiopian Orthodox Church is miaphysite at all, arguing that Ethiopia was not directly represented at Chalcedon, and that the problem is one of translation (Ayala 1981, Ephraim 2013). The Ethiopian church holds that "there were, to be sure, two natures before the Incarnation, but only one after the union: the humanity being absorbed in the divinity" (Ephraim 2013: 49). The word Tewahido, "unified," in the church's name expresses this singularity.

The Tewahido concept has not gone unchallenged. Unionists were in the seventeenth century pitted against the school of Unctionists (qibat) who maintained that Christ's humanity and divinity were initially separated and only joined through the unction of the Holy Spirit (Getatchew 1990, Marcus 1994: 43-44). This school, although ultimately defeated, was influential in the Gojjam region, and there were Unctionists in Zege within living memory. ${ }^{3}$ As explained to me by Tefera, their position was thought unacceptable because it held that Jesus did not, in his essence, share his mother's blood or flesh, meaning that Unctionism downplayed the importance of Mary - a transgression of great contemporary significance, given the rise of Protestantism in contemporary Ethiopia. 
The 1200 and 1300 s saw the consolidation of the Solomonic ideology that would continue to underpin imperial political philosophy until 1974. The key text was the Kibre Negest, Glory of Kings, compiled from various sources around this time (Levine 1974: 93, Orlowska 2006: 39). It describes the journey of the Queen of Sheba to visit King Solomon, how she learns religious law from him, and how he tricks her into sleeping with him. The king promises he will not take her by force if she does not take anything in his house by force, and then tricks her into taking water after feeding her a spicy meal. They sleep together, but that night Solomon has a dream in which he sees a brilliant heavenly sun withdraw from Israel and move to shine over Ethiopia (Budge 2000: 31).

The queen returns to Ethiopia and bears a son, who will become Emperor Menilek I. Menilek returns to Israel to learn the laws from his father, and on the way home he takes the Ark of the Covenant (Tabote S'ín), with God's permission via the Angel of the Lord, for "had it not been that God willed it Zion could not have been taken away forthwith" (Budge 2000: 61). The Ark, which according to Ethiopian tradition resides in Axum to this day, becomes the symbol of the transmission of divine sovereignty from Israel to Ethiopia, and subsequent monarchs will trace their legacy through descent from Solomon and through holy anointment.

The Ark remains a key symbol for Ethiopian Orthodoxy today. Each church contains at least one consecrated replica of the Ark of the Covenant, known as a tabot, which is understood to be the dwelling place of divinity and is the only object on which the Eucharist can be prepared. The tabot, usually made of wood and consecrated by a bishop, is a replica of the Ark of the Covenant and tablets of Moses, and is kept away from public view at all times (Hammerschmidt 1965, Pankhurst 1987, Getatchew 1988).

The tabot is, in a very real sense, what makes a church a church, and is crucial to the religious geography of Zege. It is brought out, under a shroud, to bless the waters on Epiphany (T'imqet) and local saints' days, and is guarded with intense care. It offers a kind of objectified evidence of the presence of divine grace on earth, and is absolutely integral to Orthodox practice and thinking about the matter-spirit relationship.

The tabot is also central to a classical scholarly question about the prevalence of Jewish-Hebraic influence in Ethiopian Orthodoxy (Rodinson 1964, Ullendorff 1969, Ephraim 2013, Afework 2014). The Kibre Negest draws an explicit connection between Ethiopian Christianity and Solomonic authority. Ephraim (2013: 26) describes the concentric tripartite structure of Ethiopian churches as an echo of the tabernacle of Solomon; the continued importance of dietary proscriptions is another compelling example, along with long-standing debates about the Ethiopian Sabbath (Getatchew 1988). ${ }^{4}$

It is important to recognize that the church itself is not a totally monolithic entity. Ethiopian Orthodox history is marked by factional and doctrinal debates 
and conflicts, and the relationship between monastics and the patriarchate has often been characterized by tension. The former patriarch Abune Paulos (1988: 38) describes Ethiopian monastic history as "a series of movements towards and away from the state and the church."

A few other key points in Ethiopian history are relevant to understanding Zege today. One is the Christianizing agenda of Emperor Zara Yaqob (r. 1434-68), whose vigorous promotion of the cult of Mary and the feasts and fasts of the Orthodox calendar did much to shape everyday religious practice and turn Ethiopian Orthodoxy into a form of popular moral governance (Kaplan 2014). Another is the centralization of the church and state under the Neo-Solomonids from the 1850s onward, starting with Emperor Tewodros II (r. 1855-68) (Crummey 1988, Orlowska 2006). Orthodox Christians in Zege regard Tewodros as a modernizer who also placed the Orthodox Church at the center of Ethiopian nationhood. Even his suicide after the Napier invasion of 1868 is seen as an act of heroic defiance. Tewodros has come to encapsulate imperial nostalgia (Marcus 2002) and the half-remembered dream of an Orthodox nation that stood proudly alongside others without aping the secular West. It is not for nothing, as friends proudly told me, that Tewodros was voted Ethiopian of the millennium. His combination of a centralizing, modernizing agenda and an overtly Orthodox Christian state project stands in tacit contrast to the contemporary state based upon constitutional religious equality, state secularism, and ethnic federalism.

\section{"A COIN HAS TWO SIDES": ZEGE AND THE MONASTERIES}

My efforts to reconstruct Zege's institutional history have relied on interviews with local church scholars and dignitaries, conducted with the help of Tefera Ewnetu. The resulting picture is necessarily partial and sometimes difficult to triangulate, but it nonetheless gives a strong impression of how public memory about the past operates in Zege, and how narratives of religious transformation emerge. I have been fortunate to be able to draw on the works of Binayew Tamrat (2014), Tihut Yirgu Asfaw (2009), Rahel Mesfin (2002, 1999), and Abdussamad Ahmad (1997), on whom I rely in particular for my understanding of land politics over time. I gratefully acknowledge my debt to these scholars and to Tefera, whose own knowledge has been indispensable to this study.

We have seen that Zegeña trace the history of the forest to the founding of the monasteries in the 130os. Early hagiographies refer to the "fruit" of the forest; it seems coffee is only introduced much later, in perhaps the early 1800 s (Cerulli 1946; Pankhurst 1968: 202; Merid 1988). Between the foundation of the monasteries and the mid-18oos, the Zege forest became a significant economic entity, based around the long-distance coffee trade. A key event appears to have 
occurred between 1680 and 1700, when a number of Amhara settlers arrived from somewhere to the north and received land rights from the monasteries (Binayew 2014: 8). According to Mergéta Worqé Dibebu, a seventy-two-year-old priest, church painter, and scholar resident in Mehal Zege, it was the arrivals of the late 1600 s who became the mentarí, or forest clearers. Sixteen settled in Mehal Zege and sixteen in Ura (the two parishes of the peninsula). These were the aqní abbatocch, "original fathers," whose descendants are known as balabbatocch (sing. balabbat), "those with fathers," and would, according to one key respondent, later claim the status of the true Zegeña "of the bone" (be at'int). Subsequent to these arrivals, two more groups would be recognized: the purchasers, and the former sharecroppers who had gained inheritance rights. If you could show descent from one of these groups, you could claim rist land. ${ }^{6}$

On one side were the balabbatocch, then. Alongside these was the mahber, which generally means "association" but here refers to the associated clergy. Alongside the land whose rist rights were held by the balabbatocch, mahber land was available to members of the clergy (Binayew 2014: 22). This included, according to Mislené Fantahun Tsegaye, land for yesét mahber, the "women's association": the nuns who resided in and around the peninsula. Mergéta Worqé also described the phenomenon of dinkwan merét, "tent land": this was for hosting visiting dignitaries, but was slowly taken over by local balabbatocch.

Finally, we come to the mislené and líqered, who worked with and represented the monasteries. ${ }^{7}$ These figures are the key to understanding the relationship between church and secular power. I once asked Aderaw, secretary of the local tour guides' cooperative and a descendant of church dignitaries himself, to explain mislené and líqered. I told him I was confused because there seemed to be multiple roles, and I wanted to know how to distinguish church power from yager power, power of the land. He replied, "And santimm hulett ges'ita alle" (A coin has two sides). Those who held power in the land were not separable from the monasteries, but were part of the same institutional setup, encapsulated in the mefraq, the church dining room in which monastic and community leaders would sit in strict hierarchical order around the memhir, the abbot of the monastery. The importance of the dining hall as the space in which hierarchy was legitimized should not be underestimated. Throughout this book we will see how eating and feeding in religious contexts have been the core practices by which social status was made and displayed.

There are two types of líqered: yager (of the land) and yemahber (of the church association). The yager líqered was elected from among the laity, held a high seat in the dining hall, and would organize taxation of the market, especially the coffee trade. Importantly, in Zege, this taxation was primarily due to the church rather than the crown, and so the yager líqered served under the abbot of the monastery, and had to wear the white headcloth symbolic of priesthood. This position 
was closely related to the chiqa shum, the tax collector, and neither role is filled nowadays. The yemahber líqered, by contrast, still exists, though with limited jural roles. This figure was selected by the clergy and seems to have controlled the coffee output from church lands (Binayew 2014). His key role was to organize the feeding and burial of the monks, becoming something of a benefactor and political patron. The mislené, finally, had to have a solid church education and sat at the right hand of the abbot. There are still mislené in Zege, with important roles as scholars and mediators of disputes.

The mislené and líqered both played key roles in the judgment of disputes, for which they received a fee. They served important roles as moral leaders, and were expected to be chewa, "proper." As we will see, this term has come to be associated with a more essentialized idea of noble descent by blood, as well as a certain kind of moral quality: the terms chewa and mislené sometimes denote the opposite of slaves. They remain influential figures today, but in the past they had significant economic and political power, whose moral justification was understood in terms of either their religious learning or their material and financial service to the church.

Binayew Tamrat (2014: 14) offers a useful summary of the system as a whole: under the authority of the memhir, "supreme administrator over his parish and the people residing within its territory," were two chains of authority, one more secular than the other. On the church side was the qése gebbez, the priest who guarded the tabot and (according to my interviews) kept the keys for the holy of holies. Below him were the other priests and deacons including yewicch' gebez, or "keeper of the outside," who provided wheat and wine for communion and wood for charcoal for the church. Below these was the deway, "bellringer," a church servant with some administrative responsibilities. In the other chain of authority, still below the memhir and above the laity, were the mislené and líqered, and below them the chiqa shum, the tax collector.

According to Mergéta Worqé, landlords (balabbatocch) began to appropriate positions in the church administration quite soon after their arrival. During the reign of Eyasu I (r. 1682-1706), the emperor made a visit to the peninsula, and was greeted not only by monks, but also by local balabbatocch, who bound their heads in white like priests. The emperor blessed the peninsula, saying mehalwan gennet darwan isat (her border is like fire, her middle like heaven). At this point the local dignitaries who had worn priestly headgear were given official leadership over the parishes. As Binayew (2014: 8) puts it, "In return for their loyalty or spiritual support to his administration, Emperor Iyasu I . . endowed the chief church officials of Zägé power for administration, tribute collection and court arbitration." My understanding of this story is that it captures a sense of the ambiguity of the parachurch authorities who would become so important in the political-religious life of Zege. 
This ambiguity remains in contemporary discourse about these figures. Most knowledgeable people-tour guides and local scholars-emphasize the respect that was due to men of all these positions, how they had the quality of tesaminet, being listened to, and masmammat, being able to bring others to agreement. They had to be servants of the church, and, as Tefera told me, no líqered would ever use the church's coffee for personal enrichment-they had too much respect for the church, and would only use the proceeds for church upkeep, gifts, and supplies.

The same people tell me how control of land was concentrated in these men's hands. But at least one respondent told me that someone who did not wield power in the proper fashion would not be a balabbat but an autocrat. He gave the example of one well-known and controversial local dignitary who had made large donations to churches but had also used his power to unfairly amass large amounts of wealth. This man was rich but supposedly lacked the religious knowledge and behavior befitting a proper dignitary. Instead, he used his wealth to abuse people and lord it over them. As the story has it, after the Derg confiscated his lands, he defiantly named his son Minattan, meaning "What have we lost?" (Implication: nothing, because our wealth was in cash and assets that the government did not have access to.)

From the 188 os a clearer history of the forest as an economic entity emerges. The long-range coffee trade became increasingly lucrative, due to increased British and Italian demand across trade routes in northeast Africa and the growth of Addis Ababa as a trade hub (Fernyhough 2010). Until the 1930s the slave trade expanded greatly, especially under the local kings Tekle Haymanot and Ras Hailu of Gojjam (roughly 1870-1930; Fernyhough 2010, Triulzi 1981). Agew and Muslim traders would bring slaves from Benishangul and Gumuz to the west, and they would be sold by Muslim traders in private houses in Afaf town (Abdussamad 1997). Orthodox Christians were forbidden by the Fetha Negest, the Law of Kings, from selling slaves but not from owning them (so long as they were baptized), and large numbers of slaves ended up working on church land (Pankhurst 2011). Abdussamad (1997) reports that a large number of priests were slave owners. This is quite plausible, but given what we have seen of Zege's lay-clerical power structure, it seems likely that the líqered were the dominant figures in the trade. Certainly, according to my interviews, it was often the líqered who were the largest landholders at this time.

Binayew Tamrat's (2014) history gives a vivid sense that the twentieth century was experienced in Zege as a series of secular bureaucratic encroachments on the domain of the church, long before the Derg government stripped the church of its landholdings in the mid-1970s. The Gojjamé king Ras Hailu, in particular, is remembered for exploiting the national interregnum from 1911 by appropriating large tracts of coffee land in Zege for himself (Binayew 2014: 17). After this point, the church in Zege would also become subject to land taxation in a way that it 
had not before, and the chiqa shum, the monasteries' tax collector, would report instead to the state (Binayew 2014: 46). Binayew also reports how the introduction of government schools was resisted in Zege from the 1940s until the 1960s, and how the introduction of government courts in 1947 would undermine the authority of the church and parachurch dignitaries and also deprive them of their mediators' fees.

The short Italian occupation is still well remembered in Zege. While there was certainly local resistance (Binayew 2014: 30), the story I have most often heard is that the peninsula as a whole submitted because the Italians had threatened to burn down the monasteries, as they had done in other areas. Protecting the monasteries came before anything else. There are also significant material remnants of the occupation-visiting the newly built church of Raphael, near Yiganda, Thomas, Abebe, and I were shown ruins of the walls of the Italian camp that had stood there, built, as we were told, with stones taken from the local churches.

\section{THE DERG AND AFTER}

The most abrupt change in the fortunes of the church, here as in the rest of Ethiopia, came with the socialist-military Derg government's overthrow of Emperor Haile Selassie in 1974, and their ensuing land reforms under the slogan of merét larashu (Land to the Tiller!; Haustein 2009). Almost all land under church control was redistributed among local families (Rahel 2002); Mergéta Worqé tells me that in previous generations it had been common practice for the wealthy to bequeath land to the local church. In Zege, in any case, peasants' associations were formed and land was redistributed from the church and major landlords to individual families, including many former slaves, sharecroppers, and dispossessed women. According to my friend and research assistant, Tefera, women who worked for the landlords had been "like slaves" and had to labor day and night. As he told me, beneficiaries of the reforms would sing the following lines:

Derg alem, Derg alem

Ante techeggerk,

Iñnass inji ayyenalle

Derg world, Derg world;

You (landowner) were troubled

But we got to see (the world, i.e., we benefited)

Today there are, however, landless people in Zege: some who were born after the land reforms of 1975 and were unable to inherit; some who were not in Zege during the reforms; and some, especially children of woman-headed households, who were subsequently dispossessed (Tihut 2009, Rahel 2002). Subsequent 
attempts were made by the EPRDF government to address these issues with further redistribution, but these had little success. In general, it seems that while early land reforms in the mid-1970s brought significant benefit to the landless in Zege, accusations of corruption, preferential treatment, and sexual exploitation by association members would become widespread within a few years (Tihut 2009: 88).

The situation now is that the land in Zege is broken up into small segments of roughly 0.75 hectares, run by individual households (Rahel 2002: 139). The local government bureau (qebellé) parcels out land roughly according to family size. Tihut Yirgu Asfaw (2009) presents detailed evidence of how women-headed households, in particular, have struggled with land disputes at the hands of their neighbors. Of her sample of households, 44 percent were woman-headed, a result of high levels of male labor out-migration as coffee outputs have declined somewhat (Tihut 2009: 95). Sharecropping and work-for-inheritance arrangements have become common between women landholders and landless men; marriage arrangements based on the understanding that husbands will work the land and gain inheritance rights are also reported (Tihut 2009: 103). Each of these arrangements, however, can leave women householders vulnerable to exploitation and dispossession (Tihut 2009: 106).

In general, there appears to have been a significant liberalization of gender relations in recent decades in Zege. Tefera, who is in his mid-thirties, told me that he remembered a time in his childhood when boys and girls were forbidden to walk the paths of Zege together; today young men and women associate together quite openly, and we both wondered whether the existence of a school in Afaf town had had some effect on this. Tefera also mentioned that practices such as "forced marriage," where potential brides were kidnapped and then an arrangement was negotiated through the shimgelna (panel of elders), had completely disappeared. The more acceptable traditional practice of sending three shimaglé (elders) to negotiate betrothals has also largely disappeared in favor of informal negotiation and choice marriage. There remains a role for the elders, however, in negotiating the terms of marriage and mediating marital disputes, according to Mislené Fantahun Tsegaye of Ura.

Most of my information of how shimgelna used to work comes from Mislené Fantahun, an octogenarian church singer and respected shimaglé. His account gives a particularly clear view of the changing relationship between religious knowledge and interpersonal mediation. As he explains it, the shimgelna would usually mediate in land and family disputes, as well as marriage negotiations-he told us that there were rarely violent crimes in Zege because of the monastery and the power of the sacred tabots. In each case three men would be selected by the local mahber association (in Zege, implying a lay-clerical voluntary association with responsibility for managing the churches) or by the parties: one monk, one 
elder lay mahber member, and one younger man whose role was to learn and provide an alternative perspective.

The agabi (marriage-making) shimaglé would negotiate wedding gifts from each family (which were supposed to be equal, and made in land and money rather than cattle because of Zege's ban on large livestock). The agabi shimaglé who had negotiated a betrothal would later be called on, if still alive, to negotiate in the case of marital troubles, and to try to reconcile them, but if necessary, to agree to a separation. In land disputes between villages, each side might appoint its own shimaglé to negotiate, or outsiders might be selected. A shimaglé would be selected on the basis of a calm and reflective personality, wisdom, and preferably a high degree of religious education. All of these would contribute to his tesamínnet, his quality of being listened to by others and therefore being able to bring about agreement (masmammat, "to cause to hear one another").

Today there are still shimaglé but their influence and authority are greatly reduced. As Mislené Fantahun told me, all land disputes now had to go to government court (fird bét). There is a local social court system known as mahberawi shengo, in which shimaglé adjudicate, but this is set up by the government and largely restricted to family disputes. It also involves a great deal of paperwork that did not exist before, and the potential of sanctions for shimaglé who fail to bring about resolution. Even in marital disputes, separation cannot be agreed to without reference to the government court.

The shimgelna was a key interface between the people and the ritual institutions of the church. One of their jobs was to arrange the sir'ate teklil, the ceremony of the crown by which virgin couples are married with Holy Communion. This ceremony allows no divorce (though separations could be negotiated in practice); but the mislené explained to me that these days young people were choosing their own ceremonies, and that therefore there were far fewer Communion marriages than in the past (implying both that fewer people were marrying as virgins and that more divorces were taking place).

There are signs today that Communion marriages may be on the rise again; young Orthodox Christians are certainly engaging widely and enthusiastically with the church through fasting and public displays of faith. What has greatly lessened, with great consequences for social life in Zege, is the degree to which associations of religiously educated older men act as mediators between families and the church. This role involved both bringing people together (negotiating disputes) and keeping them apart (by acting as go-betweens so that men and women did not make their own arrangements). As we will see throughout the book, the simultaneous connection and separation are characteristic of mediation in general.

While chewing khat and talking to a friend in his forties (who, as a khatchewer, was automatically far less reputable than the men we have been discussing), I asked what he thought was most different from his childhood. Apart from 
the conservatism relating to boys and girls, he lamented that the coming of the police to Afaf (a few resident officers as of the past decade) meant that people no longer resolved their own fights. In the old days, he said, if you got drunk and fought someone, you would say, "I'm sorry, I was drunk," and if necessary you would have the shimaglé. Now, the police simply lock you up for a night. This small example speaks to a broader shift away from local mediation systems toward state police and courts.

The growth of the market town of Afaf has been integral to the spread of secular government influence. There used to be a marketplace at Ura, on the peninsula, but at some point in the late 1800 s the marketplace at Afaf was established. Afaf occupies a patch of clear land at the edge of the Zege forest. One story people tell of its origins is that the fathers of Zege needed a larger place to hold meetings as their numbers expanded, hence ke af le af, "from mouth to mouth." The local historian Mergéta Worqé offers more detail, saying that the marketplace was opened under the ownership and control of one Fasil, a local landlord, who would extract rent from trading plots.

In Zege, the marketplace also marks the point of crossing from the peninsula (sacred, forested) to the rest of the world: the farmlands around, the city of Bahir Dar, and beyond. In the past, this was where visitors to Zege had to request permission from the monastic leaders to enter the peninsula itself. It was also the site of the dingay masmereq (graduating stone), the stone at which church dignitaries would in the past make all announcements and new appointments (according to Mergéta Abbi), and so was a major interface between the church associations and the general populace. Abebe told me he has still seen older men stop and pray at the stone when entering and leaving the market. Afaf is where the first government schools were built, and remains the only place with a regular police presence. It was also the locus of the slave trade until the 1930s (Abdussamad 1997). Afaf is the point where the forest ends, and as such plays a crucial intermediary role between the land of the monasteries and the surrounding area, as well as with the government.

\section{SACRIFICE, FEASTING, AND SOCIAL CHANGE}

The decline of monastic-landholder authority does not correspond to a decline in Orthodox Christian practice; in fact the opposite might be true. Across Orthodox Ethiopia, the Derg's redistribution of church lands and subjugation of the patriarchate seem to have been met, almost immediately, with a surge of grassroots participation (Clapham 1988, Bonacci 2000, Chaillot 2002). Nominally atheist, the Derg seems to have preferred to appropriate the popular energy around the church, rather than attempt to suppress popular religious practice (Donham 1999: 143). 
What we do see is a decline in funerary feasting and similar practices based on the slaughter and redistribution of meat. These semiofficial practices had long coexisted with the Orthodox liturgical orders of the church, and their reduction is described by many, especially higher-status elders, as part of a general disturbance and decline of the moral values of hospitality (and, by implication, a certain kind of hierarchy).

The general idea, as any local priest will tell you, is that the sacrifice of Christ obviated the need for animal sacrifice (meswat). ${ }^{8}$ The Eucharist remains, according to the Orthodox Church, a true sacrifice in itself, but nothing else is necessary (Kaplan 2003b: 15). However, in practice animal sacrifice has been performed in Zege in recent times and may still be during funeral rites (see chapter 6). A notable example is the practice of $f e l$.

$\mathrm{Fel}$ was practiced throughout the Haile Selassie era but started much earlier. It always involved the gift and slaughter of an ox. The way it started was that on holidays such as Christmas and Easter, a landlord (balabbat) or wealthy person would slaughter an ox and give it to the monks and the poor people who lived in the church - though at some point, as the economy worsened, they stopped doing this. Another aspect of $f e l$ was that, during droughts, groups of people would collect money to buy a virgin (dingil) ox, which local dignitaries would sacrifice and then consume together. ${ }^{9}$ Importantly, whatever remained of the meat would not be taken home, but buried in the ground at the spot of the slaughter-to pray for rain, people had to give up a part of the consumable meat. They would also bury the skins, which would otherwise be sold in the market. This kind of $f e l$ was a form of prayer, and was directed to God, but church scholars including Mergéta Worqé discouraged the practice and refused to attend. But, especially during bad times like the Italian invasion, and whenever the rain was late, people would revive the sacrifice.

There seems to have been a formalization of the $f e l$ at some point, with a " $f e l$ boss" appointed to collect contributions, which were taxed. Tefera tells me that his mother kept a receipt from 1957 (Ethiopian calendar, 1964/65 European) for one birr contribution toward the $f e l$, including tax. It is not clear, however, whether this was for the redistributive kind of $f e l$ or for prayers for rain. The practice has stopped now, but both Tefera and the Mergéta told me that people still thought in these terms, and that if the rains come late now it is quite likely that people will perform the sacrifice again, including the burial of the surplus.

$\mathrm{Fel}$, then, could be a redistributive practice that served to establish the beneficent role of the nobles as providers of life or a way to pray for rain. In the first case, it resembles the kind of feasting that has long been opposed by the government as backward and wasteful; in the latter, it is a form of offering that the church has always disapproved of. The proper way to pray and give thanks for rain is to walk the Acts of Saint Betre Maryam around the peninsula-multiple times, if 
necessary. This returns the responsibility for environmental mediation squarely within the official church purview, and is still regularly practiced today. The final factor that sealed the decline of $\mathrm{fel}$, at least for the time being, was the fear of Muslims making claims to land in Zege and the ensuing need to make sure that local practice was recognizable as properly religious. The practice has been discontinued, and the hilltop on which the sacrifice took place renamed mesqel adebabay, the square of the Cross.

The decline of sacrifice and hospitality, or their relocation within the aegis of the church, represents massive changes in how status gets figured out. The correct manner of resolving these status questions was through the distribution of food and the shedding of blood. The moral killing and consumption of animals (with Christian prayers, followed by hospitable distribution of the meat) are a key mode by which religious and secular authority become practically associated. To participate in such feasts was to bodily participate in the social order of the churchlandlord complex. At such moments, the core model of the Eucharistic feast is never far away.

Narratives of the decline of socioreligious and funerary feasting will continue to emerge throughout this book. They are integral to a particular elite understanding of how proper, moral hierarchy was reproduced in Zege. Within the scope of this narrative, the decline in hospitality signifies a sign of a general decline in trust. As we will see in the next chapter, however, fasting and the observance of calendrical prohibitions are as salient as ever. A productive way to think about this contrast is that fasting, along with the refusal to work on saints' days, distinguishes Orthodox Christians from Muslims, who fast differently, and Protestants, who reject the Orthodox fasts entirely. Fasting also asserts a religious dimension to everyday life in a context where that religious dimension is no longer institutionalized in the apparatus of the state. Traditional feasting practices, by contrast, while closely associated with the saints and the monasteries, were more concerned with organizing hierarchy and class relations within Zege society. From this perspective the shift in Orthodox practice reflects a deep change in the social stakes of religious belonging within wider Ethiopian society.

\section{NOTES}

1. Mislené (district chief; Kane 1990); literally, "one like me"; see also Bairu 1986: 296, 300).

2. Literally, "leader of the assistants."

3. Before the remapping of Ethiopia along ethnic-federal lines in the early 1990s (Donham 2002), Zege lay in the western part of Gojjam province, and a strong sense of Gojjamé cultural and political heritage remains to this day.

4. The question of how and why Judaic and Old Testament influences became established in Ethiopian Orthodoxy is far beyond the scope of this book. Ephraim (2013) and Afework (2014) offer the most detailed recent accounts. 
5. As if to demonstrate this point, Paulos's own patriarchate would be marked by conflicts between monasteries and the state and accusations of political complicity.

6. The gult, or rights to tribute issuing from the land, bestowed by the emperor, were in Zege all held by the church (Binayew 2014: 19). Rist, hereditary usage rights, could be claimed by anyone who could demonstrate descent from one of the first inhabitants, or aqní abbat (Binayew 2014, Teshale 1995: 74). As Alan Hoben (1973) describes in great detail, the Amhara cognatic descent system meant that a very large number of people could theoretically claim any particular plot of land, and actual rights would depend on being physically present and having sufficient influence or litigation skills.

7. Along with drawing on Binayew (2014), information on mislené and líqered is gathered from interviews with Mergéta Worqé, Mislené Fantahun, and Mergéta Abbi, with the assistance of Tefera Ewnetu.

8. Ephraim Isaac (2013:37) argues that the concept of meswat, along with the importance of sacrificial practice in Ethiopian Orthodoxy, is further evidence of deep Jewish and Christian influence.

9. The virginity of the animal is important for reasons of purity, beyond the usual practical reasons for the castration of oxen. 